\title{
Estrogen receptors and estetrol- dependent neuroprotective actions: a pilot study
}

\author{
Ekaterine Tskitishvili', Christel Pequeux', Carine Munaut', Renaud Viellevoye², \\ Michelle Nisolle ${ }^{3}$, Agnes Noël' ${ }^{1}$ and Jean-Michel Foidart'1 \\ 1Department of Obstetrics and Gynecology/Department of Clinical Sciences, Laboratory of Development \\ Biology and Tumor, GIGA-Cancer, University of Liege, Liege, Belgium \\ 2Department of Pediatrics, Neonatal Intensive Care Unit, University of Liege, CHR de la CITADELLE, \\ Liege, Belgium \\ ${ }^{3}$ Department of Obstetrics and Gynecology, University of Liege, CHR de la CITADELLE, Liege, Belgium
}

Correspondence should be addressed to E Tskitishvili Email

ekaterinet@hotmail.com

\begin{abstract}
Estetrol (E4) has strong antioxidative, neurogenic and angiogenic effects in neural system resulting in the attenuation of neonatal hypoxic-ischemic encephalopathy. We aimed to define the role of estrogen receptors in E4-dependent actions in neuronal cell cultures and prove the promyelinating effect of E4. In vitro the antioxidative and cell survival/ proliferating effects of $\mathrm{E} 4$ on $\mathrm{H}_{2} \mathrm{O}_{2}$-induced oxidative stress in primary hippocampal cell cultures were studied using different combinations of specific inhibitors for ER $\alpha$ (MPP dihydrochloride), ER $\beta$ (PHTTP), GPR30 (G15) and palmytoilation (2-BR). LDH activity and cell survival assays were performed. In vivo the promyelinating role of different concentrations of E4 ( $1 \mathrm{mg} / \mathrm{kg} / \mathrm{day}, 5 \mathrm{mg} / \mathrm{kg} /$ day, $10 \mathrm{mg} / \mathrm{kg} /$ day, $50 \mathrm{mg} / \mathrm{kg} /$ day) was investigated using the hypoxic-ischemic brain damage model in the 7-day-old immature rats before/after the induction of hypoxic-ischemic insult. Myelin basic protein (MBP) immunostaining was performed on brain coronal sections. Our results show that LDH activity is significantly upregulated in cell cultures where the E4's effect was completely blocked by concomitant treatment either with ER $\alpha$ and ER $\beta$ inhibitors (MPP and PHTPP, respectively), or ER $\alpha$ and $E R \beta$ inhibitors combined with 2-BR. Cell survival is significantly downregulated in cell cultures where the effect of E4 was blocked by ER $\beta$ inhibitor (PHTTP) alone. The blockage of GRP30 receptor did affect neither LDH activity nor cell survival. MBP immunostaining is significantly upregulated in E4-pretreated groups at a concentration of $5 \mathrm{mg} / \mathrm{kg} /$ day and $50 \mathrm{mg} / \mathrm{kg} /$ day E4, whereas the MBP-positive area OD ratio is significantly increased in all the E4-treated groups. E4's antioxidative actions mostly depend on ER $\alpha$ and ER $\beta$, whereas neurogenesis and possibly promyelinating activities might be realized through ER $\beta$.
\end{abstract}

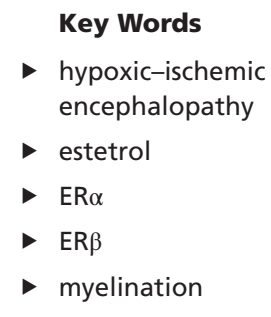

Journal of Endocrinology (2017) 232, 85-95

\section{Introduction}

Neonatal encephalopathy is mainly triggered by perinatal hypoxic-ischemic brain injury and accompanied by neurodevelopmental deficits such as learning disabilities, mental retardation and hearing and visual impairments. Neonatal hypoxic-ischemic encephalopathy (HIE) remains a serious condition that 
causes significant mortality and morbidity in near-term and term newborns; also, it does occur in premature infants as well (Volpe 2001). The brain damage due to hypoxia and ischemia results in various lesions in preterm and in term infants with the neuronal/axonal involvement of the cerebral white matter, thalamus, basal ganglia, cerebral cortex, brainstem and cerebellum (Volpe 2001). Two recent clinical trials provided updated information on mortality and neurodevelopmental outcomes in infants with moderate and severe HIE as follows: $23-27 \%$ of infant mortality was recorded prior to discharge from the neonatal intensive care unit (NICU) and $37-38 \%$ of mortality at follow-up 18-22 months later (Gluckman et al. 2005, Shankaran et al. 2005). The neurodevelopmental outcome at 18 months included mental and psychomotor development retardation, cerebral palsy (CP), epilepsy, blindness and hearing impairment (Gluckman et al. 2005, Shankaran et al. 2005). As a recent study suggests, neonatal HIE might start antenatally, implying the importance of different factors (i.e. genetic and/or infectious, and placental factors), but parturition might have importance for the final development of HIE (Martinez-Biarge et al. 2013). As a consequence, brain hypoxia and ischemia due to systemic hypoxemia and reduced cerebral blood flow (CBF) are primary reasons leading to perinatal HIE (Grow $\&$ Barks 2002, Ferriero 2004). At present, therapeutic hypothermia is considered the best neuroprotective strategy (Gluckman et al. 2005, Shankaran et al. 2005, Azzopardi et al. 2009), but neurodevelopmental deficits persist in $40-50 \%$ of patients even after hypothermia (Shankaran et al. 2005). So far, no medical treatment provides important neuroprotection against neonatal HIE.

E4 is a natural human fetal estrogen with selective estrogen receptor modulator activity (SERM) (Abot et al. 2014). Its synthesis amounts to $1 \mathrm{mg} / \mathrm{kg} /$ day at term of pregnancy and results of a cooperativity between fetal adrenals, placenta and fetal liver. It is detected in maternal urine from about 9 weeks of gestation, substantially increasing during pregnancy (Holinka et al. 2008). Our recent studies already showed that E4 has very good antioxidant, neuroprotective, neurogenic and angiogenic properties and the combined use of $\mathrm{E} 4$ with other steroids do not have any priority over the single use of E4 (Tskitishvili et al. 2014, 2016).

Estrogen receptor $\alpha(\mathrm{ER} \alpha)$ and $\beta$ (ER $\beta)$ are expressed in the human cortex and hippocampus during neurodevelopment. ER $\alpha$, detected by 9 weeks of gestation, plausibly has importance for the early neurodevelopment, whereas ER $\beta$ might have importance for later processes, such as corticogenesis (Nomura et al. 2003). E4 acts as a SERM by activating the nuclear ER $\alpha$, inhibiting its membrane form and blocking the membrane initiated steroid signaling by estradiol. Depending on the respective role of nuclear and membrane forms of ER $\alpha$ in distinct target organs, E4 may have a synergistic role with E2 (through activation of nuclear ER $\alpha$ ) or an antiestrogenic effect by blocking membrane $\mathrm{ER} \alpha$ and its activation by E2. As a consequence, E4 has biological activities distinct from E2, depending on the tissues and cells and the selective binding to the nuclear/ membrane form of ER $\alpha$ (Abot et al. 2014). In general, palmitoylation regulates $17 \beta$-estradiol-induced ER $\alpha$ degradation and transcriptional activity (La Rosa et al. 2012) and may explain the ability of ER $\alpha$ to associate to plasma membrane making possible E2-dependent rapid functions (Acconcia et al. 2004) and the same might be plausible for E4-dependent rapid functions.

Recent studies have shown that estrogen receptor ER $\beta$ expression in oligodendrocytes is required for the attenuation of clinical disease by an ER $\beta$ ligand pointing out the role of this specific receptor in myelination (Khalaj et al. 2013). It was also demonstrated that GPR30, which is uniquely localized to the endoplasmic reticulum, but not the plasma membrane, may non-genomically signal in response to estrogens by increasing the calcium flux (Revankar et al. 2005).

Our aim was to identify those estrogen receptors through which E4 can realize its antioxidative and neuroprotective actions in neuronal cells and define the possible promyelinating effect of E4.

\section{Materials and methods}

\section{In vitro studies}

Preparation of primary hippocampal neuronal cultures We prepared primary hippocampal neuronal cultures from newborn (P0) Sprague-Dawley (SD) rat pup brains according to the recently published protocols (Kaech \& Banker 2006, Beaudoin et al. 2012), which we have used in our previous study (Tskitishvili et al. 2014, 2016). Briefly, brains were dissected to separate the hippocampus region. Hippocampi were separated in dissection medium consisting of Hanks balanced salt solution (HBSS) supplemented with sodium pyruvate (100x), glucose and HEPES buffer $(10 \mathrm{mM})$, and http://joe.endocrinology-journals.org DOI: $10.1530 / J O E-16-0434$
(C) 2017 The authors Printed in Great Britain
Published by Bioscientifica Ltd 
trypsinized followed by the addition of DNase and incubation at room temperature for $5 \mathrm{~min}$. Then hippocampi were resuspended in $2.5 \mathrm{~mL}$ of plating medium consisting of minimal essential medium (MEM) with Earle's salts, supplemented with $10 \%$ of fetal bovine serum (FBS), glucose, sodium pyruvate, GlutaMax-Isupplement and penicillin/streptomycin (100×). Hippocampi were dissociated, the cell viability was evaluated and the cells were plated on poly-L-lysinecoated 24 -well $\left(5 \times 10^{4}\right.$ cells/well $)$ or 96 -well $\left(5 \times 10^{3}\right.$ cells/ well) culture plates. Cultures were incubated in a humidified $5 \% \quad \mathrm{CO}_{2} / 95 \%$ air atmosphere at $37^{\circ} \mathrm{C}$ in maintenance medium consisting of neurobasal medium, containing supplement B-27 (50x), GlutaMax-Isupplement and penicillin/streptomycin (100x). Cytosine arabinosidase (Ara-C) was added to the maintenance media $48 \mathrm{~h}$ later after plating of the cells during $24 \mathrm{~h}$. Upon changing the culture medium, the cultures were incubated for additional 3-4 days prior to use. All the chemicals and solutions were purchased from Invitrogen and Sigma-Aldrich.

\section{Cell culture stimulation with $\mathrm{H}_{2} \mathrm{O}_{2}, \mathrm{E} 4$ alone or} with different combinations of inhibitors To study the role of different estrogen receptors that mediate the antioxidant effect of E4, specific inhibitors for ER- $\alpha$, ER- $\beta$, GPR30 and palmitoylation (MPP dihydrochloride, PHTTP, G15 and 2-bromohexadecanoic acid (2-BR), respectively) were used as their efficacy was already described in some recent studies (Kajta et al. 2013, Rzemieniec et al. 2015). According to these studies, inhibitors might give unspecific effects in cell cultures by affecting the LDH release. To avoid any unspecific reaction, effects of different doses of MPP, PHTTP, G15 (from $1 \mathrm{pM}$ to $1 \mu \mathrm{M}$ of each inhibitor) and 2-BR $(1 \mathrm{pM}-40 \mu \mathrm{M})$ alone or in combination with each other in the presence or absence of either $\mathrm{E} 4$ or $\mathrm{H}_{2} \mathrm{O}_{2}$ were tested on LDH release (data not shown). Based on these observations, we have chosen the doses of inhibitors, which did not give unspecific effects and do not affect the LDH release ( $1 \mathrm{pM}$ of each inhibitor). MPP has no stimulatory activity on ER $\alpha$ or ER $\beta$, and it fully inhibits $\mathrm{ER} \alpha$ activity by E2 while having no suppressive activity on ER $\beta$ stimulation by E2 (Sun et al. 2002). PHTTP has 36-fold selectivity for $\mathrm{ER} \beta$, and it is fully effective as an ER $\beta$-antagonist while exhibiting no significant agonist effects on ER $\alpha$ or ER $\beta$. Thus, it is useful in evaluating the biological activity of ER $\beta$ (Compton et al. 2004). G15 binds to GPR30 with high affinity and acts as an antagonist of estrogen signaling through GPR30 (Dennis et al. 2009). 2-BR is a non-selective inhibitor of lipid metabolism and a general inhibitor of protein S-palmitoylation (Davda et al. 2013).

MPP dihydrochloride, PHTTP and G15 were purchased from Tocris Bioscience (Bristol, UK), whereas 2-BR - from Sigma-Aldrich. All inhibitors were dissolved in DMSO and further diluted in culture medium at a final concentration of $0.1 \%$ DMSO. Primary hippocampal cell cultures prepared from newborn rat pups, at day 7 after plating cells, were treated with $100 \mu \mathrm{M}$ of $\mathrm{H}_{2} \mathrm{O}_{2}$ for 30 min (Merck KGaA) and then treated with $\mathrm{E} 4$ alone or in combination with MPP (1 pM), or PHTTP (1 pM), or $\mathrm{G} 15(1 \mathrm{pM})$ and/or 2 -BR $(1 \mathrm{pM})$ for $1 \mathrm{~h}$ as follows: $\mathrm{E} 4+1 \mathrm{pM}$ MPP, E4+1 pM PHTTP, E4+1 pM MPP +1 pM PHTTP, E4+1 pM 2-BR; $\quad \mathrm{E} 4+1 \mathrm{pM} \quad 2-\mathrm{BR}+1 \mathrm{pM} \quad \mathrm{MPP}$, $\mathrm{E} 4+1 \mathrm{pM} 2-\mathrm{BR}+1 \mathrm{pMMPP}+1 \mathrm{pMPHTTP}, \mathrm{E} 4+1 \mathrm{pM}$ G15. Cell cultures treated only with $100 \mu \mathrm{M}$ of $\mathrm{H}_{2} \mathrm{O}_{2}$ for $1 \mathrm{~h}$ 30 min were used as controls. E4 (Mithra Pharmaceuticals, Liege, Belgium) was used at a concentration of $3.25 \mathrm{mM}$ as one of the successful concentrations used in our previous in vitro studies (Tskitishvili et al. 2014, 2016). LDH activity was measured in supernatants. The rest of the cell cultures were subjected to the cell viability assay.

Evaluation of lactate dehydrogenase (LDH) activity and cell viability $T o$ evaluate the consequence of existence of oxidative stress and the cell viability in primary hippocampal cell cultures stimulated by different concentrations of $\mathrm{E} 4$ alone or in combination with different estrogen receptor inhibitors, LDH activity (Abcam) and cell viability assays (Promega Corporation) were performed. All the procedures were performed in accordance to the manufacturer's protocol as previously described (Tskitishvili et al. 2014, 2016). Each condition was repeated 3-6 times.

\section{In vivo studies}

We obtained SD pregnant rats from Janvier (Janvier Labs, Le Genest-Saint-Isle, France). After delivery, the newborn pups were reared with their dams at $25^{\circ} \mathrm{C}$. All experimental procedures were approved by the University of Liege (Belgium) Ethical Committee. E4 was diluted in saline solution. The vehicle group animals were IP injected a saline solution. Neither injections nor the carotid artery ligation and exposure to hypoxia were performed in sham group.

Neuroprotective (pretreatment) effect of E4 To study the neuroprotective effect of E4, 10 newborn rat pups were assigned to each group from postnatal day 4 as

Published by Bioscientifica Ltd 
followed: sham group, vehicle-treated group, $1 \mathrm{mg} / \mathrm{kg} / \mathrm{per}$ day, $5 \mathrm{mg} / \mathrm{kg} /$ per day, $10 \mathrm{mg} / \mathrm{kg} /$ per day and $50 \mathrm{mg} / \mathrm{kg} /$ per day E4-treated groups. From postnatal day 4 (P4), pups were injected IP either with vehicle (vehicle group) or with E4 $(1 \mathrm{mg} / \mathrm{kg} / \mathrm{day}, 5 \mathrm{mg} / \mathrm{kg} /$ day, $10 \mathrm{mg} / \mathrm{kg} /$ day or $50 \mathrm{mg} / \mathrm{kg} /$ day) in accordance to the group assignment. At postnatal day 7 (P7), a model of hypoxia-ischemia in immature 7-day-old rat pups was used with modifications (Vanucci \& Vanucci 2005). Briefly, $30 \mathrm{~min}$ after the last injection of either $\mathrm{E} 4$ or vehicle, animals were anesthetized with isoflurane (induction 3.0\%, maintenance-1.50\%), and the left common carotid artery was double-ligated and severed. After the procedure, the pups were returned to their dams and allowed to recover for $1 \mathrm{~h}$. The pups were then placed in the humidified hypoxic in vivo cabinet (CoyLab, Grass Lake, MI, USA). Hypoxia was produced by the inhalation of decreased concentrations of oxygen for $20 \mathrm{~min}$ from $11 \%$ to $8 \%$ oxygen balanced by nitrogen, followed by the inhalation of $8 \%$ oxygen and $92 \%$ nitrogen for $35 \mathrm{~min}$ as already described previously (Tskitishvili et al. 2014, 2016). All manipulations were performed at $37^{\circ} \mathrm{C}$. Rat pups recovered with their dams and reared normally until being killed at P14.

Therapeutic effect of E4 To study the therapeutic effect of $\mathrm{E} 4$ after hypoxic-ischemic insult, 10 newborn rat pups were assigned to each group at P7 as followed: sham group, vehicle-treated group, $1 \mathrm{mg} / \mathrm{kg} / \mathrm{per}$ day, $5 \mathrm{mg} /$ $\mathrm{kg} /$ per day, $10 \mathrm{mg} / \mathrm{kg} /$ per day and $50 \mathrm{mg} / \mathrm{kg} /$ per day E4 groups. At P7, a model of hypoxia-ischemia in immature 7-day-old rat pups was used with modifications (Vanucci \& Vanucci 2005). Briefly, animals were anesthetized with isoflurane (induction $3.0 \%$ maintenance-1.5.0\%) and the left common carotid artery was double-ligated and severed in the rat pups of the vehicle and $\mathrm{E} 4$ groups. After the procedure, the pups were returned to their dams allowed to recover for $1 \mathrm{~h}$ and then placed in the humidified hypoxic in vivo cabinet (CoyLab). Hypoxia was produced by the inhalation of decreasing concentrations of oxygen for $20 \mathrm{~min}$ from $11 \%$ to $8 \%$ balanced by nitrogen, followed by inhalation of $8 \%$ oxygen and $92 \%$ nitrogen for $35 \mathrm{~min}$. All manipulations were performed at $37^{\circ} \mathrm{C}$ as already described previously (Tskitishvili et al. 2014, 2016). Upon retrieval from hypoxia chamber, rat pups were injected IP either by vehicle (vehicle group) or by $\mathrm{E} 4(1 \mathrm{mg} / \mathrm{kg} / \mathrm{day}, 5 \mathrm{mg} / \mathrm{kg} /$ day, $10 \mathrm{mg} / \mathrm{kg} /$ day or $50 \mathrm{mg} / \mathrm{kg} /$ day) in accordance to the group assignment. Rat pups recovered with their dams until being killed at P14.
Measurement of rat pups rectal temperature To determine the possible effect of $\mathrm{E} 4$ treatment on rat pups body and brain temperatures, the measurement of the temperature per rectum was done by using multiple thermometer (BAT-10R) and a specific RET-4 probe (Bio Medical Instruments, Zollnitz, Germany) after hypoxic insult at 0-, 2- and 4-h time points as described previously (Tskitishvili et al. 2014, 2016). The variability of the rectal/body temperature was kept at low level by making the temperature measurements in a $25^{\circ} \mathrm{C}$ room (Feng et al. 2005). Rat pups rectal temperature was not significantly different between the study groups (data not shown).

Brain and blood samples preparation The pups were killed at P14. Preparation of the brain and blood samples was performed according to our protocol already used previously (Tskitishvili et al. 2014, 2016). Briefly, animals were deeply anesthetized. Blood was withdrawn quickly and the serum samples were stored at $-80^{\circ} \mathrm{C}$ before being used. Transcardial perfusion of animals was performed with $0.9 \%$ saline solution followed by the perfusion of the $4 \%$ paraformaldehyde in PBS at $4^{\circ} \mathrm{C}$. The brains were being quickly removed, weighed and fixed for $24 \mathrm{~h}$, followed by embedment in paraffin.

ELISA to detect blood serum S100B and glial fibrillary acidic protein (GFAP) (brain damage markers) ELISAs for serum S100B (CUSABIO BIOTECH Co., Ltd., Wuhan, China), and GFAP (USCN Life Science Inc., Wuhan, China) were performed according to the manufacturers' recommendations.

MBP staining The sections were processed for immunohistochemical detection of neuronal cytoskeletal disruption. For antigen retrieval, the sections were heated in $10 \mathrm{mmol} / \mathrm{L}$ citrate buffer $(\mathrm{pH} 6.0)$ at $100^{\circ} \mathrm{C}$ for $10 \mathrm{~min}$. Endogenous peroxidase activity was blocked with $3 \%$ hydrogen peroxide for $10 \mathrm{~min}$ and after a second blocking with 5\% normal goat serum, the sections were incubated with MBP 1:1000 (mouse monoclonal antibody; Sigma) overnight at room temperature. After rinsing, biotinylated goat anti-mouse immunoglobulin G (Vector, Burlingame, CA, USA) was added, and antibody detection was performed with the avidin-biotin complex method (Vector), with 3,30-diaminobenzidine (DAB) and the nickel as chromogens. After the reaction with $\mathrm{DAB}$ and the nickel, the slides were washed, dehydrated and coverslipped. The area with intact white matter

Published by Bioscientifica Ltd. 
displayed staining with MBP, whereas the damaged area showed a loss of MBP staining. 10 samples from each study group of both study designs were analyzed with the aid of an image scanner (Nanozoomer Virtual Microscopy, Hamamatsu, Tokyo, Japan) and the ImageJ software (NIH) as previously described (Tskitishvili et al. 2014, 2016). The optical density (OD) of MBP-positive areas in the ipsilateral and contralateral hemispheres was measured. The ratio of the MBP-positive areas OD was calculated as the MBP-positive area OD of the ipsilateral hemisphere divided by the MBP-positive area of the contralateral hemisphere. The ratio of the MBP-positive area OD in sham-operated animal group was considered by default as 1.0.

\section{Correlation studies between the optical density} (OD) of MBP-positive area ratio, brain damage markers, glial fibrillary acidic protein (GFAP) and S100B and the brain weight Previous studies already demonstrated that the reduced brain weight is usually attributed mainly to the loss of white matter (Harper et al. 1985, De la Monte 1988), and there is a relationship between expression patterns of myelin protein levels and brain weight, age at death and postmortem interval (Lewoh et al. 2005). Recently, a significant correlation was found between the markers for myelination and the brain weight (Lewoh et al. 2005). Brain weights of animals from study groups were measured along with the MBP-positive area OD ratio, the blood GFAP and S100B expression, and correlation studies were performed.

\section{Statistical analysis}

The Statview statistics package (Abacus Concepts) was used for statistical analysis. An ANOVA followed by Fisher's PLSD, Scheffe's and Bonferroni/Dunn post hoc tests and Fisher's $r$ to $z$ tests, respectively, were used for statistical comparisons and correlative studies with $P \leq 0.05$ considered as significant. All values (except for correlations) are expressed as mean \pm S.E.M.
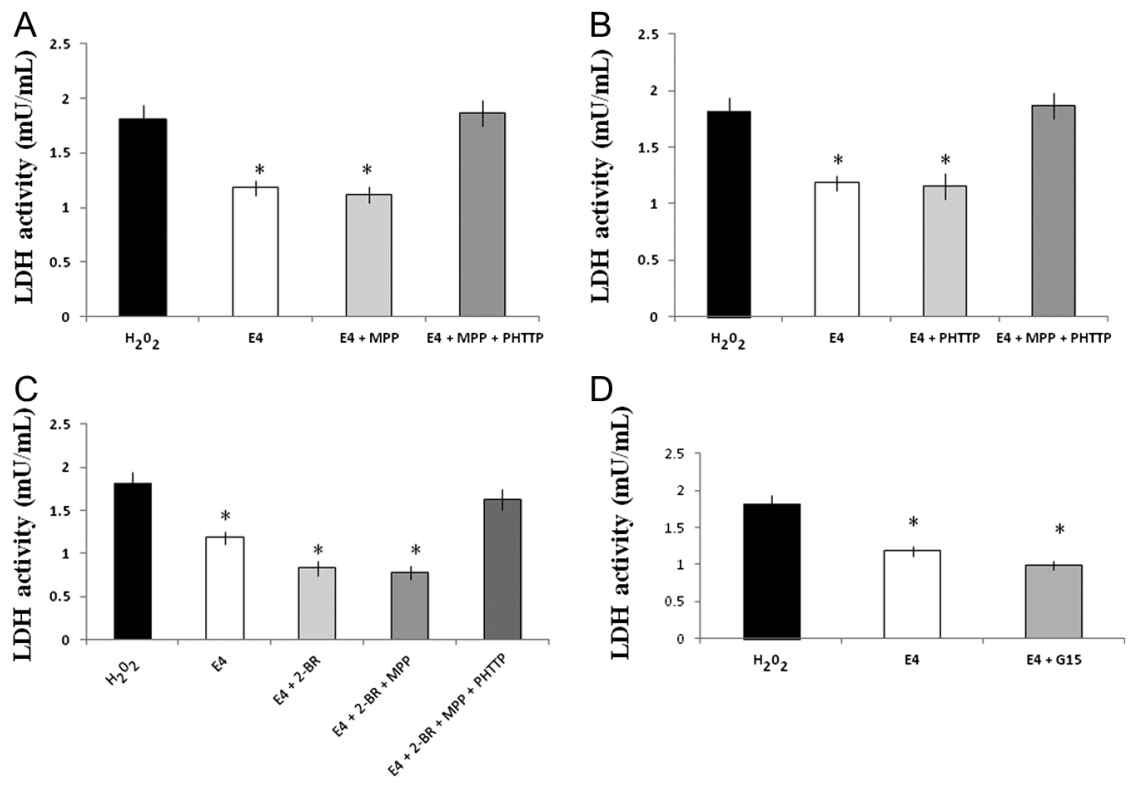

Figure 1

Effect of E4 in combination with different receptor inhibitors on $\mathrm{LDH}$ activity in primary hippocampal neuronal cultures subjected to the $\mathrm{H}_{2} \mathrm{O}_{2}$-induced oxidative stress. Primary hippocampal cell cultures were exposed to $3.25 \mathrm{mM}$ E4 alone or in combination with MPP, PHTTP, G15 and/or 2-BR after induction of oxidative stress. (A) LDH activity was significantly decreased by treatment with E4 alone or in combination with ER- $\alpha$ inhibitor MPP compared to the $\mathrm{H}_{2} \mathrm{O}_{2}$-treated cell cultures or cultures combinedly treated by E4+ MPP + PHTTP. Combined use of MPP and PHTTP significantly increased the LDH activity compared to the cells treated by E4 alone or in combination with MPP. (B) LDH activity was significantly decreased by treatment with E4 alone or in combination with ER- $\beta$ inhibitor PHTTP compared to the $\mathrm{H}_{2} \mathrm{O}_{2}$-treated cell cultures or cultures combinedly treated by E4 + MPP + PHTTP. Combined use of MPP and PHTTP significantly increased the LDH compared to the cell cultures treated by E4 alone or in combination with PHTTP. (C) Inhibition of palmitoylation alone or in combination with MPP significantly downregulated LDH activity compared to the $\mathrm{H}_{2} \mathrm{O}_{2}$-treated cells or to those treated by E4 alone. Combination of E4 with 2-BR, MPP and PHTTP significantly upregulated LDH activity compared to the cell cultures treated by E4 or 2-BR alone or in combination with MPP. (D) Cell cultures treated by E4 alone or in combination with GPR30 inhibitor G15 had significantly lower LDH activity compared to the cultures treated by $\mathrm{H}_{2} \mathrm{O}_{2}$ alone. No significant difference was observed between the cells treated by E4 alone or in combination with G15.

http://joe.endocrinology-journals.org DOI: 10.1530/JOE-16-0434
(C) 2017 The authors Printed in Great Britain
Published by Bioscientifica Ltd 


\section{Results}

\section{Effect of E4 treatment with estrogen receptor inhibitors} on $\mathrm{H}_{2} \mathrm{O}_{2}$-induced LDH activity in primary hippocampal cell cultures

To study the role of estrogen receptors in E4-dependent antioxidative effects in neuronal cells, primary hippocampal cell cultures were exposed to $3.25 \mathrm{mM} \mathrm{E} 4$ alone or in combination with different estrogen receptor inhibitors and/or palmitoylation inhibitor after induction of oxidative stress. As shown in Fig. 1A, the LDH activity level was significantly decreased by treatment with E4 alone or in combination with MPP, and only concomitant treatment of cells by E4 along with MPP and PHTTP blocked the antioxidative activity of E4 and significantly increased the LDH activity level compared to the cell cultures treated by E4 alone. Similar pattern of activities was observed when E4 was used in combination with PHTTP alone, and only the combined use of E4 with MPP and PHTTP completely blocked the E4-dependent effect by increasing the $\mathrm{LDH}$ activity to the same levels than that in the $\mathrm{H}_{2} \mathrm{O}_{2}$ treated cells (Fig. 1B). As shown in Fig. 1C, inhibition of palmitoylation alone (E4+2-BR group) or in combination with MPP significantly decreased LDH activity, suggesting that the combined blockage of $\mathrm{ER} \alpha$ and palmitoylation is not sufficient to inhibit the E4-dependent effects. In the presence of 2-BR, the LDH activity was significantly lower than that in $\mathrm{H}_{2} \mathrm{O}_{2}$-treated cell cultures, also in those treated by $\mathrm{E} 4$ alone, suggesting that the inhibition of palmitoylation even potentiated the E4-dependent antioxidative effect. Finally, combination of E4 with 2-BR, MPP and PHTTP completely blocked the antioxidative effects of E4 compared to the use of E4 or 2-BR alone or in combination with MPP once again suggesting the role of both receptors, $\mathrm{ER} \alpha$ and $\mathrm{ER} \beta$ (Fig. 1C). Inhibition of GPR30 receptor did not block the E4 actions resulting in significant decrease of LDH activity compared to the cell cultures treated solely by $\mathrm{H}_{2} \mathrm{O}_{2}$ (Fig. 1D).

\section{Effect of E4 treatment with estrogen receptor inhibitors on $\mathrm{H}_{2} \mathrm{O}_{2}$-induced cell viability in primary hippocampal cell cultures}

To study the role of estrogen receptors in E4-dependent cell survival/proliferation effects in neuronal cells, primary hippocampal cell cultures were exposed to $3.25 \mathrm{mM} \mathrm{E4}$
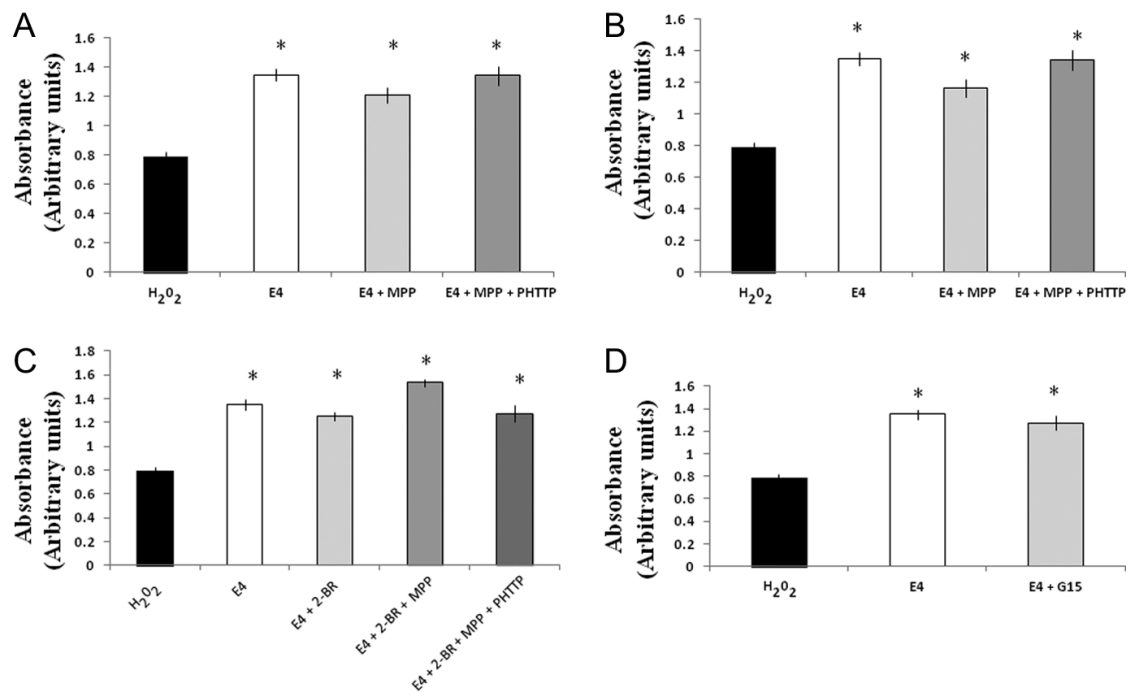

\section{Figure 2}

Effect of E4 in combination with different receptor inhibitors on cell survival in primary hippocampal neuronal cultures subjected to the $\mathrm{H}_{2} \mathrm{O}_{2}$-induced oxidative stress. Primary hippocampal cell cultures were exposed to $3.25 \mathrm{mM}$ E4 alone or in combination with MPP, PHTTP, G15 and/or 2-BR after induction of oxidative stress. (A) Cell survival rate was significantly upregulated in cells treated by E4 alone or in combination either with MPP or MPP + PHTTP compared to cells solely treated by $\mathrm{H}_{2} \mathrm{O}_{2}$. (B) Cultures treated either by E4 alone or with PHTTP with/without MPP had significantly upregulated cell survival rate compared to cells treated by $\mathrm{H}_{2} \mathrm{O}_{2}$ alone. Cells combinedly treated by E4 with PHTTP had significantly lower cell survival rate than the cell cultures treated by E4 alone. (C) Cells treated either by E4 alone or in combination with 2-BR, MPP and/or PHTTP had significantly higher cell survival rate compared to the cells solely treated by $\mathrm{H}_{2} \mathrm{O}_{2}$. Treatment of cultures by E4 and 2-BR along with MPP resulted in significant upregulation of cell survival compared to the cultures treated by 2-BR alone or in combination with MPP and PHTTP. No significant difference was observed between the cells treated by E4 alone or those treated by different combinations of E4, 2-BR, MPP and/or PHTTP. (D) Treatment of cell cultures by E4 alone or in combination with G15 significantly upregulated the cell survival rate compared to cell cultures treated by $\mathrm{H}_{2} \mathrm{O}_{2}$. No significant difference was observed between cells treated by E4 alone or in combination with G15.

http://joe.endocrinology-journals.org DOI: 10.1530/JOE-16-0434 (c) 2017 The authors Printed in Great Britain
Published by Bioscientifica Ltd 
alone or in combination with different estrogen receptorspecific inhibitors and/or palmitoylation inhibitor after induction of oxidative stress. As shown in Fig. 2A, cell survival rate was significantly higher in cells treated by $\mathrm{E} 4$ alone or in combination either with MPP alone or when associated with PHTTP suggesting that neither inhibition of ER $\alpha$ alone nor inhibition of both receptors (ER $\alpha$ and ER $\beta$ ) blocked the E4-dependent cell survival activity. Inhibition of ER $\beta$ alone significantly downregulated the cell survival rate compared to cells treated by $\mathrm{E} 4$ alone or in combination with MPP and PHTTP (Fig. 2B). Figure 2C demonstrates that all cells treated either by $\mathrm{E} 4$ alone or in combination with different combinations of 2-BR, MPP and PHTTP had significantly higher cell survival rate compared to the cells treated by $\mathrm{H}_{2} \mathrm{O}_{2}$ alone, and inhibition of palmitoylation along with inhibition of ERo activity resulted in a significantly higher cell survival compared to the cultures treated by 2-BR alone or in combination with MPP and PHTTP suggesting that ER $\alpha$ (probably membrane form of the receptor) does not affect the E4-dependent cell survival/proliferation actions
(Fig. 2C). Combination of E4 with G15 significantly upregulates the cell survival rate along with cell cultures treated by $\mathrm{E} 4$ alone compared to the cells treated by $\mathrm{H}_{2} \mathrm{O}_{2}$ alone (Fig. 2D).

\section{Myelin basic protein staining}

Loss of MBP staining due to hypoxic-ischemic insult was used as a marker of white matter damage. In both study designs, in the vehicle groups, there was a loss of MBP staining in the left hemisphere (Figs 3A and 4A), in the subcortical region and the cingulum as one of the main white matter region of the brain (Figs 3B and $4 \mathrm{~B})$. In neuroprotective model, the ratio of MBP-positive area OD was significantly higher in the sham-operated, and in the $5 \mathrm{mg} / \mathrm{kg} / \mathrm{day}$ and $50 \mathrm{mg} / \mathrm{kg} /$ day E4-pretreated groups than that in the vehicle-treated group (Fig. 3C), whereas all the E4-exposed groups in the therapeutic model had significantly higher MBP-positive area OD ratio along with sham group compared to the vehicle group (Fig. 4C).

\section{Neuroprotective effect}

A
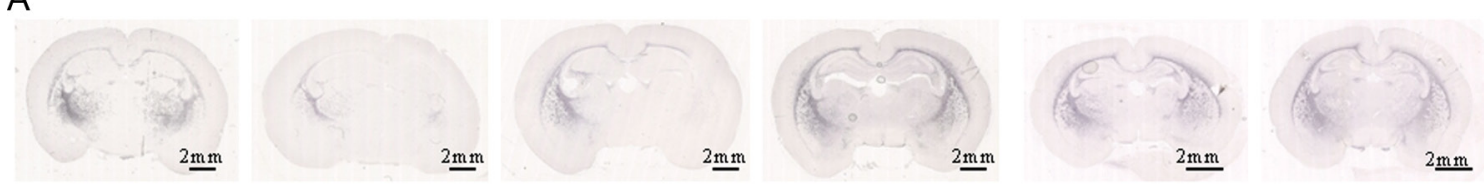

B

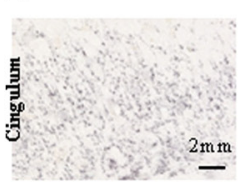

Sham

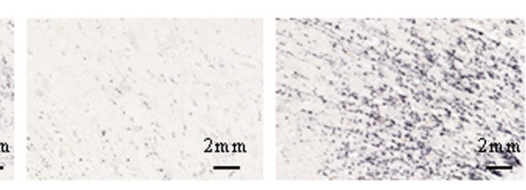

$1 \mathrm{mg} / \mathrm{kg}$ E4

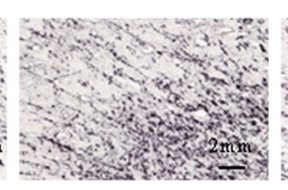

$5 \mathrm{mg} / \mathrm{kg} \mathrm{E4}$

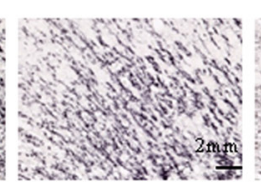

$10 \mathrm{mg} / \mathrm{kg}$ E4

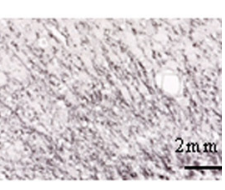

$50 \mathrm{mg} / \mathrm{kg} \mathrm{E4}$
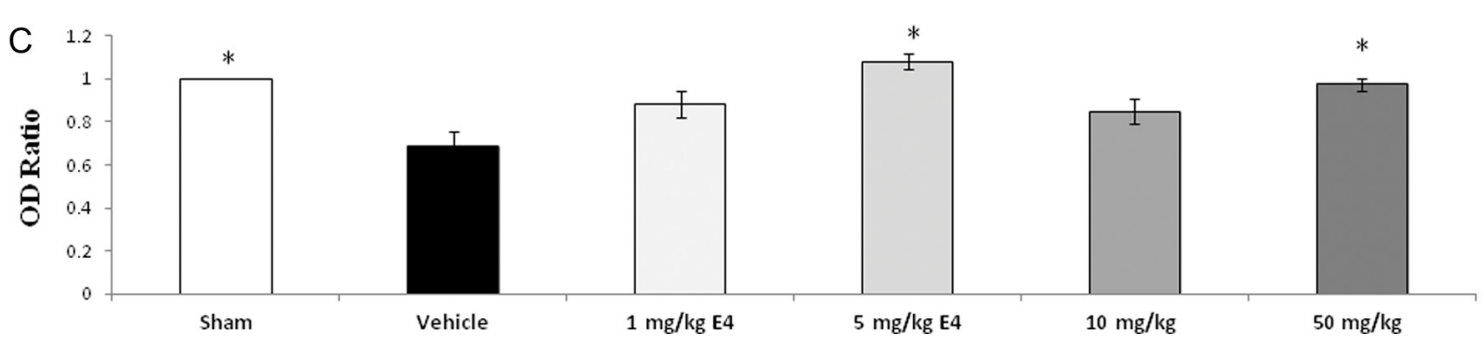

Figure 3

Myelin basic protein (MBP) staining of brain coronal sections in rat pups pretreated with estetrol. (A) MBP staining of brain coronal sections (scale bar: $2 \mathrm{~mm}$ ) is shown. (B) MBP staining of cingulum of the left hemisphere is shown (scale bar: $2 \mathrm{~mm}$ ). (C) The ratio of the MBP-positive areas OD ratio was calculated as the MBP-positive area OD of the ipsilateral hemisphere divided by the MBP-positive area OD of the contralateral hemisphere. 10 samples from each study group were analyzed. The ratio of the MBP-positive area OD in the Sham group was considered by default as 1.0 . The MBP-positive area OD ratio was significantly higher in sham-operated animals and the $5 \mathrm{mg} / \mathrm{kg} / \mathrm{day}$ and $50 \mathrm{mg} / \mathrm{kg} / \mathrm{day}$ E4-pretreated groups compared to the vehicle group. All measurements are expressed as mean \pm S.E.M. ${ }^{*} P<0.05$.

http://joe.endocrinology-journals.org DOI: $10.1530 / J O E-16-0434$
() 2017 The authors Printed in Great Britain
Published by Bioscientifica Ltd 
Therapeutic effect

A
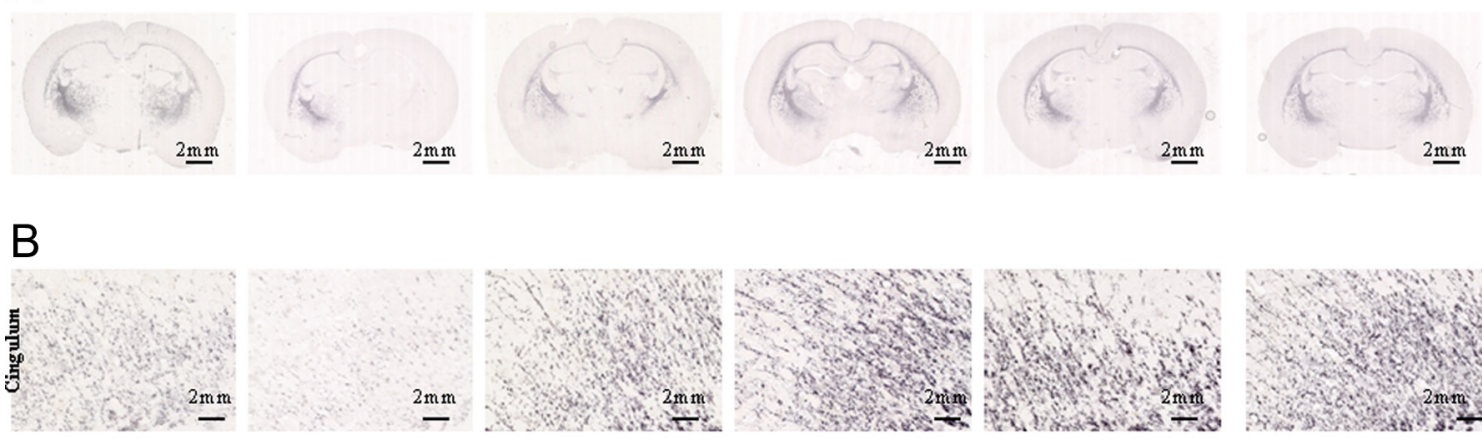

Sham
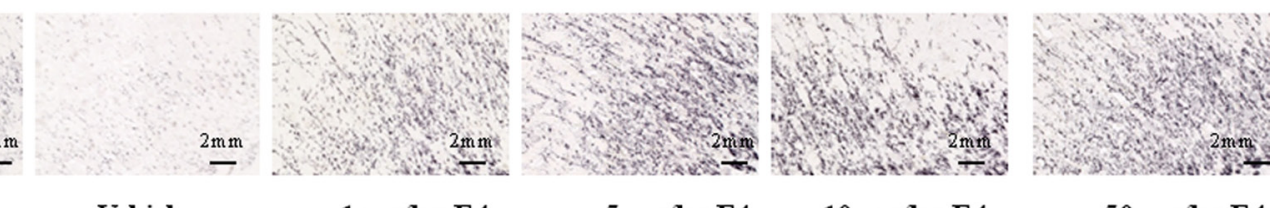

$1 \mathrm{mg} / \mathrm{kg}$ E4

$5 \mathrm{mg} / \mathrm{kg} \mathrm{E4}$

$10 \mathrm{mg} / \mathrm{kg}$ E4

$50 \mathrm{mg} / \mathrm{kg}$ E4

C
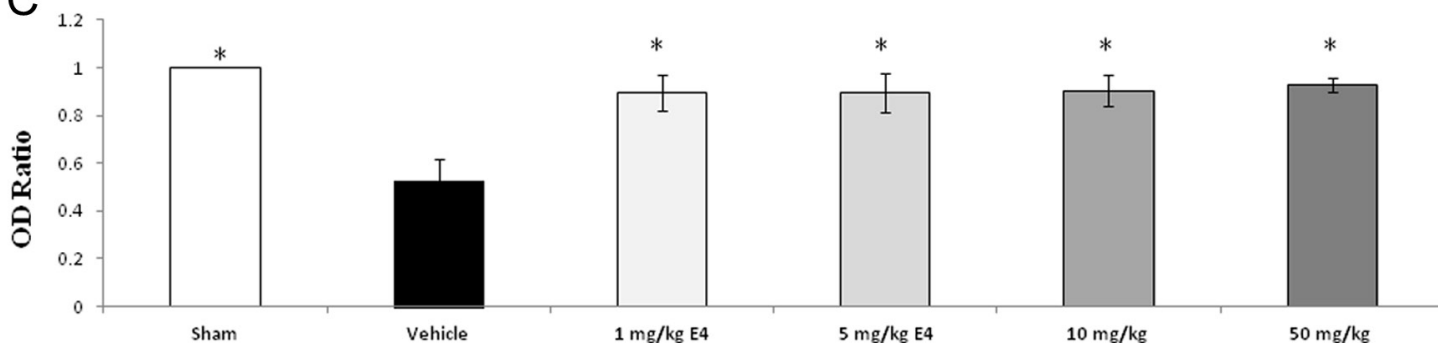

Figure 4

Myelin basic protein (MBP) staining of brain coronal sections in rat pups treated with estetrol. (A) MBP staining of brain coronal sections (scale bar: $2 \mathrm{~mm}$ ) is shown. (B) MBP staining of cingulum of the left hemisphere is shown (scale bar: $2 \mathrm{~mm}$ ). (C) The ratio of the MBP-positive areas OD ratio was calculated as the MBP-positive area OD of the ipsilateral hemisphere divided by the MBP-positive area OD of the contralateral hemisphere. 10 samples from each study group were analyzed. The ratio of the MBP-positive area OD in the sham group was considered by default as 1.0. The MBP-positive area $O D$ ratio was significantly higher in sham-operated animals and the $1 \mathrm{mg} / \mathrm{kg} /$ day, $5 \mathrm{mg} / \mathrm{kg} / \mathrm{day}, 10 \mathrm{mg} / \mathrm{kg} /$ day and $50 \mathrm{mg} / \mathrm{kg} /$ day E4-treated groups compared to the vehicle group. All measurements are expressed as mean \pm s.E.M. ${ }^{*} P<0.05$.

\section{Correlation studies between the brain weight, blood GFAP and S100B expression and MBP-positive area OD ratio}

To study the significance of the white matter damage marker MBP, and the brain damage markers GFAP and $\mathrm{S} 100 \mathrm{~B}$ in connection with the brain weight, correlation studies were performed. In most groups from neuroprotective and therapeutic models, no correlation was found between the MBP-positive area OD ratio, GFAP, S100B and the brain weights (data not shown). However, in neuroprotective model, significant positive correlation was observed between the MBP-positive area OD ratio and the brain weights $(r=0.707, P=0.0198)$ in the vehicle group.

\section{Discussion}

In this study, we attempted to identify ER receptors responsible for E4-mediated neuroprotection in vitro and evaluate the pro-myelinating efficacy of E4 in vivo.
The expression of $\operatorname{ER} \alpha$ and $\operatorname{ER} \beta$ displays different spatial-temporal patterns during human cortical and hippocampal development and suggest that both ERs may play distinct roles in several processes related to prenatal brain development (Gonzalez et al. 2007). Knowledge of the region-specific expression of each ER subtype is critical to better understand the actions of estrogens on human brain (Gonzalez et al. 2007). The cortical plate, which develops into the future six-layered neocortex, appears first at 8-9 gestational weeks and increases in thickness until neurogenesis is completed after midgestation; however, myelination starts before birth and is not completed in some regions of the brain before adulthood (Feng et al. 2005). Highly divergent and sometimes opposing functions for the two receptors have been reported in studies of ER $\alpha$ knockout and ER $\beta$-knockout mice (Hewitt \& Korach 2003). In addition to their effects on gene expression (their genomic effects), these ERs are also associated with rapid cellular signaling (non-genomic effects) that

Published by Bioscientifica Ltd. 
are thought to be mediated primarily by membraneassociated forms of these receptors (Hammes \& Levin 2007).

In oligodendrocytes (OLGs) and neuronal cells, ERs are expressed in a different way (Zhang et al. 2004). According to recent studies, ER $\alpha$ and ER $\beta$ mRNA was detected in OLGs: in vitro ER $\beta$ is localized in cytoplasm of OLGs, whereas ER $\alpha$ is detected in the nuclei of OLGs. In vivo ER $\beta$ is detected in cytoplasm and myelin of OLGs, and it is associated with the outer and inner layers of the myelin sheath, whereas in neurons mainly with cytoplasm, and ER $\alpha$ is detected in the nuclei of neurons (Zhang et al. 2004). Some recent studies show that the myelin sheath contains an array of proteins and lipids including G proteins (Larocca et al. 1991, Dyer 2002, Razandi et al. 2003). Classical steroid receptors, localized in the cytosol and/or nucleus, traditionally mediate their primary effects at the genomic level. In recent years, a large number of reports have described membrane-associated estrogen receptors, either similar to or distinct from the classical nuclear estrogen receptors (Toran-Allerand et al. 2002, Razandi et al. 2003, Acconcia et al. 2004). These receptors have been postulated to mediate aspects of cellular estrogen function, including traditional genomic (transcriptional) signaling as well as non-genomic (rapid) signaling (Evans \& Muldoon 1991, Govind \& Thampan 2003). These non-genomic signaling events include pathways that are traditionally thought of as arising from transmembrane growth factor receptors and G-proteincoupled receptors, whereas some reports described estrogen-binding sites on intracellular membranes (Wang et al. 2002, La Rosa et al. 2012), other reports suggest that palmitoylation or phosphorylation (La Rosa et al. 2012) may target classical ERs to the cytoplasmic side of the plasma membrane. In general, palmitoylation is necessary for ER $\alpha$ transcriptional activity and inhibition of ER $\alpha$ palmitoylation constitutively addresses ER $\alpha$ to the nuclear matrix resulting in the basal degradation of the neo-synthesized ER $\alpha$ (Suzuki et al. 2007).

Different studies enlighten the role of estrogen receptors in the central neuronal system (CNS): both estrogen receptors ER $\alpha$ and ER $\beta$ play pivotal functional roles, insofar as knocking out either of these receptors blocks the ability of estradiol to increase neurogenesis (Dubal et al. 2001, Suzuki et al. 2007). ERo mediates protection of the brain and carries the far-reaching implications for the selective targeting of ERs in the treatment and prevention of neural dysfunction associated with normal aging or brain injury (Dubal et al. 2001). Our results demonstrate for the first time that only concomitant inhibition of $\mathrm{ER} \alpha$ and $\mathrm{ER} \beta$ receptor activities is necessary to diminish the E4's antioxidative effects and promote further upregulation of LDH activity suggesting that $\mathrm{E} 4$ might be an equally important ligand for both estrogen receptors. One limitation of our study might be connected to failure to prove whether depalmitoylation is connected somehow to the membrane receptor ER $\alpha$.

Recent studies proved that the neuroprotective actions of estrogens also depend on their strong antioxidant specifications and positively correlate with the number of the phenolic moiety in their structure; existence of the free phenolic $\mathrm{OH}$ group is important for protection against oxidative stress (Prokai et al. 2006). The highest number of the free phenolic $\mathrm{OH}$ groups among estrogens is in E4, suggesting the strong antioxidant effects of this compound. Much research has been done to study the mitochondria as a primary target for estrogen-mediated pathways (Nilsen \& Brinton 2004, Nilsen et al. 2006, 2007, Brinton 2008, Irwin et al. 2008). Our study determines clearly that antioxidative activity of E4 depends on ER activity and is not limited to its 'dismissal' capacity to inactivate free oxygen radicals through the $\mathrm{OH}$ groups.

As it was defined, the potential role of ER $\beta$ expression in cells of oligodendrocyte (OL) lineage in ER $\beta$ ligandmediated neuroprotection is important, and it results in the upregulation of myelination (Khalaj et al. 2013). Moreover, neuroprotection might be mediated through ER $\alpha$ in astrocytes exclusively (Spence et al. 2011). As we observed, in primary hippocampal cell cultures, the cell survival rate was significantly downregulated only when the ER $\beta$ receptor was completely blocked, suggesting the role of ER $\beta$ in neurogenesis. We can speculate that promyelinating effects of $\mathrm{E} 4$ are also realized through ER $\beta$. We did not observe any significant effect of palmitoylation inhibition on cell survival/proliferation.

The rat begins to form myelin at about 10-12 days postnatally. At 15 days of age, about $4 \mathrm{mg}$ of myelin can be isolated from 1 brain (Siegel et al. 1999). This amount increases 6-fold during the next 15 days; and at 6 months of age, $60 \mathrm{mg}$ of myelin can be isolated from 1 brain. This represents an increase of about $1500 \%$ over 15-day-old animals. During the same 5.5-month period, the brain weight increases by $50-60 \%$ in long-term brain development (Siegel et al. 1999). Thus, myelination and the brain weight might be correlated. According to our studies, pretreatment of rat pups by $5 \mathrm{mg} / \mathrm{kg} /$ day and $50 \mathrm{mg} / \mathrm{kg} / \mathrm{day} \mathrm{E} 4$ before hypoxic-ischemic injury, and treatment by all $\mathrm{E} 4$ doses after $\mathrm{HI}$ brain injury significantly

Published by Bioscientifica Ltd. 
upregulates myelination. Correlation studies detected significant positive correlation between the MBP-positive area $\mathrm{OD}$ ratio and the brain weights exclusively in the vehicles from the neuroprotective model, whereas in E4-pretreated or -treated groups, this correlation could no longer be observed suggesting that the promyelinating effect of E4 is not the only factor that affects the brain weight in the model of E4-mediated neuroprotection.

In conclusion, $\mathrm{E} 4$ is an estrogen with SERM properties. Further studies are necessary to uncover the role of this compound during antenatal neurodevelopment and in attenuation of neonatal hypoxic-ischemic brain damage.

\section{Declaration of interest}

Prof J M Foidart is extraordinary professor at the University of Liege and Senior Scientific officer of Mithra Pharmaceuticals Inc (Belgium).

\section{Funding}

This research was supported by grants from the Fonds de la Recherche Scientifique - FNRS (F.R.S. - FNRS, Belgium): FRSM 3.4557.12, FRSM 3.4526.12, FRSM 3.4567.11, PDR T.0091.14, the Fonds spéciaux de la Recherche (University of Liege, Belgium): FSRC-12/64, FSRC-12/92, FSRC14/89, FSRC-14/65, FSRC-14/109, FSRC-14/62, the Fonds Léon Frederica (University of Liege, Belgium), the Direction Générale Opérationnelle de I'Economie, de I'Emploi et de la Recherche from the Service Public de Wallonie (SPW, Belgium): WB Health project No. 1318051, WB Health project No. 1318039, WB Health project No. 1318030, WB Health project No. 1318071, WB Health project No. 1318023, the Interuniversity Attraction Poles Programme-Belgian Science Policy (Brussels, Belgium): IAP Phase VII - P7/03, and the Actions de Recherche Concertées (University of Liege, Belgium): A.R.C. 11/16-02.

\section{Acknowledgments}

The authors thank Isabelle Dasoul and Erika Konradowski for their technical help.

\section{References}

Abot A, Fontaine C, Buscato M, Solinhac R, Flouriot G, Fabre A, Drougard A, Rajan S, Laine M, Milon A, et al. 2014 The uterine and vascular actions of estetrol delineate a distinctive profile of estrogen receptor modulation, uncoupling nuclear and membrane activation. EMBO Molecular Medicine 6 1328-1346. (doi:10.15252/ emmm.201404112)

Acconcia F, Ascenzi P, Fabozzi G, Visca P \& Marino M 2004 S-palmitoylation modulates human estrogen receptor-alpha functions. Biochemical and Biophysical Research Communications $\mathbf{3 1 6}$ 878-883. (doi:10.1016/j.bbrc.2004.02.129)

Azzopardi DV, Strohm B, Edwards AD, Dyet L, Halliday HL, Juszczak E, Kapellou O, Levene M, Marlow N, Porter E, et al. 2009 Moderate hypothermia to treat perinatal asphyxial encephalopathy. New England Journal of Medicine 361 1349-1358. (doi:10.1056/ NEJMoa0900854)
Beaudoin GM 3rd, Lee SH, Singh D, Yuan Y, Ng YG, Reichardt LF $\&$ Arikkath J 2012 Culturing pyramidal neurons from the early postnatal mouse hippocampus and cortex. Nature Protocols 7 1741-1754. (doi:10.1038/nprot.2012.099)

Brinton RD 2008 The healthy cell bias of estrogen action: mitochondrial bioenergetics and neurological implications. Trends in Neurosciences 31 529-537. (doi:10.1016/j.tins.2008.07.003)

Compton DR, Sheng S, Carlson KE, Rebacz NA, Lee IY, Katzenellenbogen BS \& Katzenellenbogen JA 2004 Pyrazol [1,5-a] pyrimidines: estrogen receptor ligandspossessing estrogen receptor beat antagonist activity. Journal of Medicinal Chemistry 47 5872-5893. (doi:10.1021/jm049631k)

Davda D, El Azzouny MA, Tom CT, Hernandez JL, Majmudar JD, Kennedy RT \& Martin BR 2013 Profiling targets of the irreversible palmitoylation inhibitor 2-bromopalmitate. ACS Chemical Biology $\mathbf{8}$ 1912-1917. (doi:10.1021/cb400380s)

De la Monte SM 1988 Disproportionate atrophy of cerebral white matter in chronic alcoholics. Archives of Neurology 45 990-992. (doi:10.1001/ archneur.1988.00520330076013)

Dennis MK, Burai R, Ramesh C, Petrie WK, Alcon SN, Nayak TK, Bologa CG, Leitao A, Brailoiu E, Deliu E, et al. 2009 In vivo effects of a GPR30 antagonist. Nature Chemical Biology 5 421-427. (doi:10.1038/ nchembio.168)

Dubal DB, Zhu H, Yu J, Rau SW, Shughrue PJ, Merchenthaler I, Kindy MS \& Wise PM 2001 Estrogen receptor a, not b, is a critical link in estradiol-mediated protection against brain injury. PNAS 98 1952-1957. (doi:10.1073/pnas.041483198)

Dyer CA 2002 The structure and function of myelin: from inert membrane to perfusion pump. Neurochemical Research 27 1279-1292. (doi:10.1023/A:1021611430052)

Evans AC Jr \& Muldoon TG 1991 Characterization of estrogen-binding sites associated with the endoplasmic reticulum of rat uterus. Steroids 56 59-65. (doi:10.1016/0039-128X(91)90125-F)

Feng Y, Fratkins JD \& LeBlanc MH 2005 Estrogen attenuates hypoxicischemic brain injury in neonatal rats. European Journal of Pharmacology 507 77-86. (doi:10.1016/j.ejphar.2004.11.039)

Ferriero DM 2004 Neonatal brain injury. New England Journal of Medicine 351 1985-1995. (doi:10.1056/NEJMra041996)

Gonzalez M, Cabrera-Socorro A, Perez-Garcia CG, Fraser JD, Lopez FJ, Alonso R \& Meyer G 2007 Distribution patterns of estrogen receptor alpha and beta in the human cortex and hippocampus during development and adulthood. Journal of Comparative Neurology $\mathbf{5 0 3}$ 790-802. (doi:10.1002/cne.21419)

Govind AP \& Thampan RV 2003 Membrane associated estrogen receptors and related proteins: localization at the plasma membrane and the endoplasmic reticulum. Molecular and Cellular Biochemistry 253 233-240. (doi:10.1023/A:1026068017309)

Grow J \& Barks JD 2002 Pathogenesis of hypoxic-ischemic cerebral injury in the term infant: current concepts. Clinics in Perinatology 29 585-602. (doi:10.1016/S0095-5108(02)00059-3)

Gluckman PD, Wyatt JS, Azzopardi D, Ballard R, Edwards AD, Ferriero DM, Polin RA, Robertson CM, Thoresen M, Whitelaw A, et al. 2005 Selective head cooling with mild systemic hypothermia after neonatal encephalopathy: multicenter randomised trial. Lancet $\mathbf{6 5}$ 663-670. (doi:10.1016/S0140-6736(05)17946-X)

Hammes SR \& Levin ER 2007 Extranuclear steroid receptors: nature and actions. Endocrine Reviews 28 726-741. (doi:10.1210/er.2007-0022)

Harper CG, Kril JJ \& Holloway RL 1985 Brain shrinkage in chronic alcoholics: a pathological study. British Medical Journal 290 501-504. (doi:10.1136/bmj.290.6467.501)

Hewitt SC \& Korach KS 2003 Oestrogen receptor knockout mice: roles for oestrogen receptors alpha and beta in reproductive tissues. Reproduction 125 143-149. (doi:10.1530/rep.0.1250143)

Holinka CF, Diczfalusy E, Coeling Bennink HJTC 2008 Estetrol: a unique steroid in human pregnancy. Journal of Steroid Biochemistry and Molecular Biology 110 138-143. (doi:10.1016/j.jsbmb.2008.03.027) 
Irwin RW, Yao J, Hamilton RT, Cadenas E, Brinton RD \& Nilsen J 2008 Progesterone and estrogen regulate oxidative metabolism in brain mitochondria. Endocrinology 149 3167-3175. (doi:10.1210/en.20071227)

Kaech S \& Banker G 2006 Culuring hippocampal neurons. Nature Protocols 1 2406-2415. (doi:10.1038/nprot.2006.356)

Khalaj AJ, Yoon JH, Nakai J, Winchester Z, Moore SM, Yoo T, Martinez-Torres L, Kumar S, Itoh N, Kaushalya S, et al. 2013 Estrogen receptor (ER) $\beta$ expression in oligodendrocytes is required for attenuation of clinical disease by an ER $\beta$ ligand. PNAS 110 19125-19130. (doi:10.1073/pnas.1311763110)

Kajta M, Rzemieniec J, Litwa E, Lason W, Lenartowicz M, Krzeptowski W $\&$ Wojtowicz A 2013 The key involvement of estrogen receptor $\beta$ and G-protein-coupled receptor 30 in the neuroprotective action of daidzein. Neuroscience 238 345-360. (doi:10.1016/j.neuroscience.2013.02.005)

Larocca JN, Golly F \& Ledeen RW 1991 Detection of G proteins in purified bovine brain myelin. Journal of Neurochemistry 57 30-38. (doi:10.1111/j.1471-4159.1991.tb02095.x)

La Rosa P, Pesiri V, Leclerq G, Marino M \& Acconcia F 2012 Palmitoylation regulates $17 \beta$-estradiol-induced estrogen receptor- $\alpha$ degradation and transcriptional activity. Molecular Endocrinology 26 762-774. (doi:10.1210/me.2011-1208)

Lewoh JM, Wixey J, Harper CG \& Dodd PR 2005 Expression of MBP, PLP, MAG, CNP, and GFAP in the human alcoholic brain. AlcoholismClinical and Experimental Research 29 1698-1705. (doi:10.1097/01. alc.0000179406.98868.59)

Martinez-Biarge M, Diez-Sebastian J, Wusthoff CJ, Mercuri E \& Cowan FM 2013 Antepartum and intrapartum factors preceding neonatal hypoxic-ischemic encephalopathy. Pediatrics 132 e952-e959. (doi:10.1542/peds.2013-0511)

Nilsen J \& Brinton RD 2004 Mitochondria as therapeutic targets of estrogen action in the central nervous system. Current Drug Targets: CNS and Neurological Disorders 3 297-313. (doi:10.2174/1568007043337193)

Nilsen J, Chen S, Irwin RW, Iwamoto S \& Brinton RD 2006 Estrogen protects neuronal cells from amyloid beta-induced apoptosis via regulation of mitochondrial proteins and function. BMC Neuroscience 7 74. (doi:10.1186/1471-2202-7-74)

Nilsen J, Irwin RW, Gallaher TK \& Brinton RD 2007 Estradiol in vivo regulation of brain mitochondrial proteome. Journal of Neuroscience 27 14069-14077. (doi:10.1523/JNEUROSCI.4391-07.2007)

Nomura M, Korach KS, Pfaff DW \& Ogawa S 2003 Estrogen receptor b (ERb) protein levels in neurons depend on estrogen receptor a (ERa) gene expression and on its ligand in a brain region-specific manner. Molecular Brain Research 110 7-14. (doi:10.1016/S0169-328X(02)00544-2)

Prokai L, Prokai-Tatrai K, Perjési P \& Simpkins JW 2006 Mechanistic insights into the direct antioxidant effects of estrogens. Drug Development Research 66 118-125. (doi:10.1002/ddr.20050)

Razandi M, Pedram A, Park ST \& Levin ER 2003 Proximal events in signaling by plasma membrane estrogen receptors. Journal of Biological Chemistry 278 2701-2712. (doi:10.1074/jbc.M205692200)

Revankar CM, Cimino DF, Sklar LA, Arterburn JB \& Prossnitz ER 2005 A transmembrane intracellular estrogen receptor mediates rapid cell signaling. Science 307 1625-1630. (doi:10.1126/science.1106943)
Rzemieniec J, Litwa E, Wnuk A, Lason W, Gołas A, Krzeptowski W \& Kajta M 2015 Neuroprotective action of raloxifene against hypoxiainduced damage in mouse hippocampal cells depends on ER $\alpha$ but not ER $\beta$ or GPR30 signaling. Journal of Steroid Biochemistry and Molecular Biology 146 26-37. (doi:10.1016/j.jsbmb.2014.05.005)

Shankaran S, Laptook AR, Ehrenkranz RA, Tyson JE, McDonald SA, Donovan EF, Fanaroff AA, Poole WK, Wright LL, Higgins RD, et al. 2005 Whole-body hypothermia for neonates with hypoxic-ischemic encephalopathy. New England Journal of Medicine 353 1574-1584. (doi:10.1056/NEJMcps050929)

Siegel GJ, Agranoff BW, Albers RW, Fisher SK \& Uhler MD 1999 Basic Neurochemistry: Molecular, Cellular and Medical Aspects. Chapter: Developmental Biology of Myelin, 6th edition. Philadelphia, PA, USA: Lippincott-Raven.

Spence RD, Hamby ME, Umeda E, Itoh N, Du S, Wisdom AJ, Cao Y, Bondar G, Lam J, Ao Y, et al. 2011 Neuroprotection mediated through estrogen receptor- $\alpha$ in astrocytes. PNAS 108 8867-8872. (doi:10.1073/ pnas.1103833108)

Sun J, Huang YR, Harrington WR, Sheng S, Katzenellenbogen JA, \& Katzenellenbogen BS 2002 Antagonists selective for estrogen receptor alpha. Endocrinology 143 941-947. (doi:10.1210/endo.143.3.8704)

Suzuki S, Gerhold LM, Bottner M, Rau SW, Dela Cruz C, Yang E, Zhu H, Yu J, Cashion AB, Kindy MS, et al. 2007 Estradiol enhances neurogenesis following ischemic stroke through estrogen receptors a and b. Journal of Comparative Neurology 500 1064-1075. (doi:10.1002/cne.21240)

Toran-Allerand CD, Guan X, MacLusky NJ, Horvath TL, Diano S, Singh M, Connolly ES Jr, Nethrapalli IS \& Tinnikov A 2002 ER-X: a novel, plasma membrane-associated, putative estrogen receptor that is regulated during development and after ischemic brain injury. Journal of Neuroscience 22 8391-8401.

Tskitishvili E, Nisolle M, Munaut C, Pequeux C, Gerard C, Noel A \& Foidart JM 2014 Estetrol attenuates neonatal hypoxic-ischemic brain injury. Experimental Neurology 261 298-307. (doi:10.1016/j. expneurol.2014.07.015)

Tskitishvili E, Pequeux C, Munaut C, Viellevoye R, Nisolle M, Noel A \& Foidart JM 2016 Use of estetrol with other steroids for attenuation of neonatal hypoxic-ischemic brain injury: to combine or not to combine? Oncotarget 7 33722-33743. (doi:10.18632/oncotarget.9591)

Vanucci RC \& Vanucci S 2005 Perinatal hypoxic-ischemic brain damage: evolution of an animal model. Developmental Neuroscience 27 81-86. (doi:10.1159/000085978)

Volpe JJ 2001 Perinatal brain injury; from pathogenesis to neuroprotection. Mental Retardation and Developmental Disabilities Research Reviews 7 56. (doi:10.1002/1098-2779(200102)7:1<56::AIDMRDD1008>3.0.CO;2-A)

Wang RA, Mazumdar A, Vadlamudi RK \& Kumar R 2002 P21-activated kinase-1 phosphorylates and transactivates estrogen receptor-alpha and promotes hyperplasia in mammary epithelium. EMBO Journal 21 5437-5447. (doi:10.1093/emboj/cdf543)

Zhang Z, Cerghet M, Mullins C, Williamson M, Bessert D \& Skoff R 2004 Comparison of in vivo and in vitro subcellular localization of estrogen receptors $\mathrm{a}$ and $\mathrm{b}$ in oligodendrocytes. Journal of Neurochemistry 89 674-684. (doi:10.1111/j.1471-4159.2004.02388.x)

Received in final form 5 October 2016

Accepted 31 October 2016

Accepted Preprint published online 31 October 2016 http://joe.endocrinology-journals.org

DOI: 10.1530/JOE-16-0434
(C) 2017 The authors Printed in Great Britain
Published by Bioscientifica Ltd. 